\title{
The study on supported Fe and FeMo hydrotreating catalysts by combining Mössbauer spectroscopy and ordinary gamma- ray transmission
}

Citation for published version (APA):

Ramselaar, W. L. T. M., Crajé, M. W. J., Gerkema, E., Hadders, R. H., Loef, van, J. J., Beer, de, V. H. J., \& Kraan, van der, A. M. (1988). The study on supported Fe and FeMo hydrotreating catalysts by combining Mössbauer spectroscopy and ordinary gamma-ray transmission. Hyperfine Interactions, 41(1-4), 697-700. https://doi.org/10.1007/BF02400486

DOI:

10.1007/BF02400486

Document status and date:

Published: 01/01/1988

Document Version:

Publisher's PDF, also known as Version of Record (includes final page, issue and volume numbers)

Please check the document version of this publication:

- A submitted manuscript is the version of the article upon submission and before peer-review. There can be important differences between the submitted version and the official published version of record. People interested in the research are advised to contact the author for the final version of the publication, or visit the $\mathrm{DOI}$ to the publisher's website.

- The final author version and the galley proof are versions of the publication after peer review.

- The final published version features the final layout of the paper including the volume, issue and page numbers.

Link to publication

\footnotetext{
General rights

- You may freely distribute the URL identifying the publication in the public portal. follow below link for the End User Agreement:

www.tue.nl/taverne

Take down policy

If you believe that this document breaches copyright please contact us at:

openaccess@tue.nl

providing details and we will investigate your claim.
}

Copyright and moral rights for the publications made accessible in the public portal are retained by the authors and/or other copyright owners and it is a condition of accessing publications that users recognise and abide by the legal requirements associated with these rights.

- Users may download and print one copy of any publication from the public portal for the purpose of private study or research.

- You may not further distribute the material or use it for any profit-making activity or commercial gain

If the publication is distributed under the terms of Article $25 \mathrm{fa}$ of the Dutch Copyright Act, indicated by the "Taverne" license above, please 


\title{
THE STUDY ON SUPPORTED Fe AND FeMo HYDROTREATING CATALYSTS BY COMBINING MÖSSBAUER SPECTROSCOPY AND ORDINARY $\gamma$-RAY TRANSMISSION
}

W.L.T.M. RAMSELAAR, M.W.J. CRAJÉ, E. GERKEMA, R.H. HADDERS, J.J. VAN LOEF, V.H.J. DE BEER* and A.M. VAN DER KRAAN

\author{
Interuniversitair Reactor Instituut, $2629 \mathrm{JB}$ Delft, The Netherlands \\ * Laboratory for Inorganic Chemistry and Catalysis, Eindhoven University of Technology, \\ P.O. Box 513, $5600 \mathrm{MB}$ Eindhoven, The Netherlands
}

\begin{abstract}
From in-situ MOssbauer spectra recorded at room temperature it is concluded that the support material (carbon or alumina) influences the degree of sulfidation of Fe and FeMo hydrotreating catalysts. For the latter a Fe-Mo-S phase is observed. By combining Mossbauer spectroscopy and ordinary $\gamma$-ray spectroscopy the sulfur uptake by the catalyst has been studied.
\end{abstract}

\section{INTRODUCTION}

Hydrotreating catalysts are used in the upgrading of fossil fuel fractions. Several processes take place simultaneously, such as hydrocracking, removal of sulfur and nitrogen and hydrogenation of unsaturated hydrocarbons. Commonly, this is done by passing the hyddrocarbon feed together with $\mathrm{H}_{2}$ over a catalyst consisting of sulfided Co and Mo supported on a high surface alumina at temperatures around $673 \mathrm{~K}$. Mbssbauer Emission Spectroscopy has been very successful in the characterization of these Industrially used catalysts $/ 1 /$.

Over the last years carbon has attracted considerable attention as a support material /2/. Carbon-supported iron sulfide can play a role in hydroprocessing heavy crudes and coal derived liquids either as active phase or as promoter of $\mathrm{MoS}_{2}$. In order to optimize the performance of these catalysts it is necessary to get insight into the origin and structure of the active phase.

We have studied earlier the transition of the oxidic precursor into the sulfidic catalyst for $\mathrm{Fe} / \mathrm{C}$ and FeMo/C /3,4/. Here, we report a comparison between carbon- and alumina-supported catalysts. Before studying the sulfidic phase under reaction conditions we have investigated the sulfidation of the catalysts at room temperature. Special attention is paid to the possible occurence during the presulfidation process of an intermediate phase in the catalyst with a life time short compared to the time required to record the full Mossbauer spectrum. This has been done by measuring the $\gamma$-ray transmission as a function of time at constant (positive and negative) velocities corresponding to one resonant energy characteristic for the compound of interest and one non-resonant energy. The difference between both $\gamma$-ray transmissions yields information about the amount of the Intermediate phase present in the catalyst as a function of time.

Furthermore we have combined Mbssbauer spectroscopy and ordinary $\gamma$-ray transmission in order to study the sulfur uptake by the catalyst.

\section{EXPERIMENTAL}

The catalysts were prepared by pore volume impregnation of NORIT RX3-extra activated carbon $\left(1190 \mathrm{~m}^{2} / \mathrm{g}\right)$ and Ketjen $\mathrm{CK} 300 \mathrm{r}-\mathrm{Al}_{2} \mathrm{O}_{3}\left(270 \mathrm{~m}^{2} / \mathrm{g}\right)$ with aqueous solutions of $\left(\mathrm{NH}_{4}\right) 6 \mathrm{MO}_{7} \mathrm{O}_{24} \cdot 4 \mathrm{H}_{2} \mathrm{O}$ (Merck, $>99 \%$ ) and $\mathrm{Fe}\left(\mathrm{NO}_{3}\right)_{3} \cdot 9 \mathrm{H}_{2} \mathrm{O}$ (Merck, p.a.). The latter was enriched in $57 \mathrm{Fe}$. The Mo phase was deposited first in two steps with intermediate drying in static air at a temperature up to $383 \mathrm{~K}$. The Feloading of the catalysts was $0.15 \mathrm{at} / \mathrm{nm}^{2}$, the Mo-loading $0.60 \mathrm{at} / \mathrm{nm}^{2}$. After the catalysts had been dried in a $100 \mathrm{ml} / \mathrm{min}$ airflow they were subjected to an additional $\mathrm{H}_{2}$-treatment at temperatures up to $393 \mathrm{~K}$. (for details see /3,4/)

Sulfiding of the catalysts took place in a Mossbauer in-situ reactor $/ 5 /$ in a $\mathrm{H}_{2} \mathrm{~S} / \mathrm{H}_{2}$ gas mixture. Details about the applied sulfidation procedure are given elsewhere $/ 3,4 /$.

(C) J.C. Baltzer A.G., Scientific Publishing Company 
MUssbauer spectra were recorded at $293 \mathrm{~K}$, using a $57 \mathrm{Co}$ in $\mathrm{Rh}$ source at room temperature. Doppler velocities are given relative to SNP at $293 \mathrm{~K}$.

\section{RESULTS AND DISCUSSION}

In Figs. 1 a,b the spectra of the sulfided carbon and alumina-supported Fe and FeMo catalysts are given. The catalysts have been subjected to various successive sulfidation treatments. Only the spectra after the final treatment up to $773 \mathrm{~K}$ are shown here.

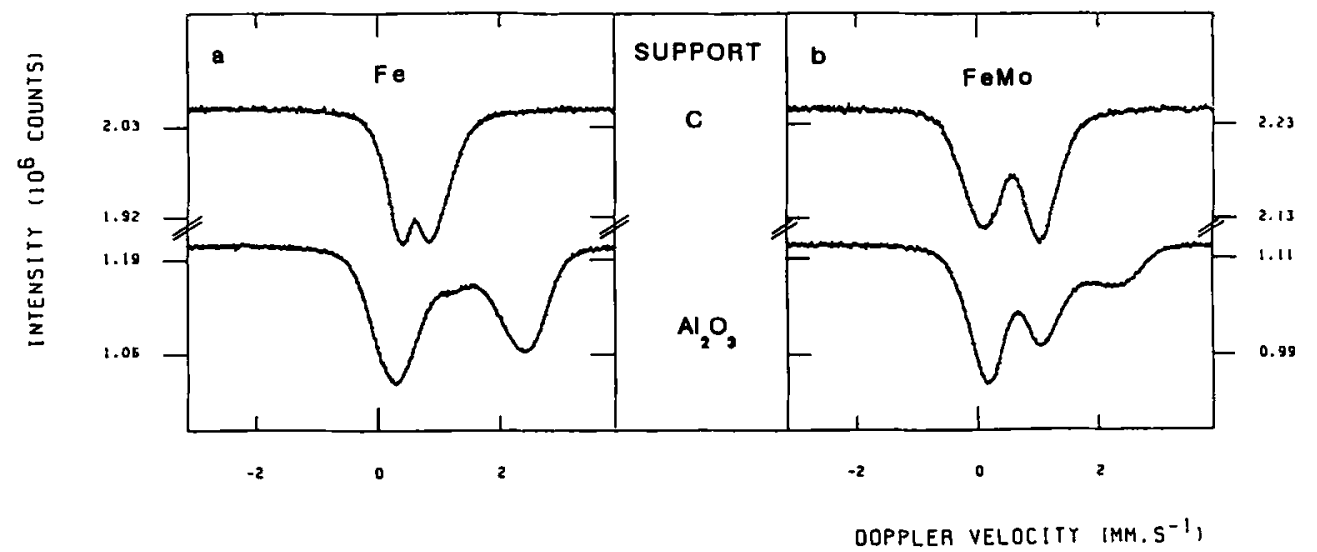

Fig. 1 Møssbauer spectra recorded at room temperature of carbon and aluminasupported Fe (Fig. 1 a) and FeMo (Fig. 1 b) catalysts. The catalysts have been subjected to various sulfidation treatments, the last one being up to $773 \mathrm{~K}$.

It is noticed that both for the carbon as well as for the alumina-supported catalysts the presence of Mo has influenced the sulfidic phase formed. In the FeMo catalysts a mixed Fe-Mo-sulfide phase similar to the so-called Co-Mo-S phase in CoMo catalysts $/ 1 /$ is formed. Furthermore, it is shown in Figs. 1 a,b that the composition of the sulfided catalysts depends on the kind of support used. For the alumina-supported catalysts a high-spin $\mathrm{Fe}^{2+}$-contribution is observed even after the final high temperature sulfidation treatment. This contribution is largest for the $\mathrm{Fe} / \mathrm{Al}_{2} \mathrm{O}_{3}$ catalyst. For carbon-supported $\mathrm{Fe}$ and FeMo catalysts the highspin $\mathrm{Fe}^{2+}$-contribution is only observed after sulfidation treatments at temperatures $\leq 473 \mathrm{~K} / 3,4 /$. The presence of the high-spin $\mathrm{Fe}^{2+}$-contribution indicates an incomplete transformation of the oxidic precursor into a sulfidic state. From computer analyses of the spectra it follows that besides the high-spin $\mathrm{Fe}^{2+}$ contribution the spectra of the carbon and alumina-supported Fe and FeMo catalysts contain the same subspectra. Hence, these experiments show that the degree of sulfidation depends on the kind of support.

In order to get more information about the time dependence of the formation of the high-spin Fe $\mathrm{Fe}^{+}$-phase at room temperature, we have measured at constant (positive and negative) velocity the transmission of the $Y$-rays as a function of time while the catalyst is exposed to the sulfiding gas mixture. The positive velocity corresponds to the positive resonant absorption position of the doublet of the high-spin $\mathrm{Fe}^{2+}$-contribution $(2.5 \mathrm{~mm} / \mathrm{s})$, while the negative velocity corresponds to a non-resonant energy (see Fig. 1). The difference between both $Y-r a y$ transmissions yields exclusively information about the amount of high-spin $\mathrm{Fe}^{2+}$ phase formed.

In Fig. $2 \mathrm{a}, \mathrm{b}$ the difference between the $\mathrm{y}$-ray transmissions as a function of time are shown for the $\mathrm{Fe} / \mathrm{C}$ and $\mathrm{Fe} / \mathrm{Al}_{2} \mathrm{O}_{3}$ catalysts. The results of the FeMo catalysts are essentially the same. For both catalysts the high-spin Fe ${ }^{2+}$-phase is formed as soon as the $\mathrm{H}_{2} \mathrm{~S} / \mathrm{H}_{2}$ gas mixture enters the reactor. This behavipur 
indicates that the transition of the oxidic precursor into the high-spin $\mathrm{Fe}^{2+}$ phase proceeds relatively easy. However, it turns out that the development in time

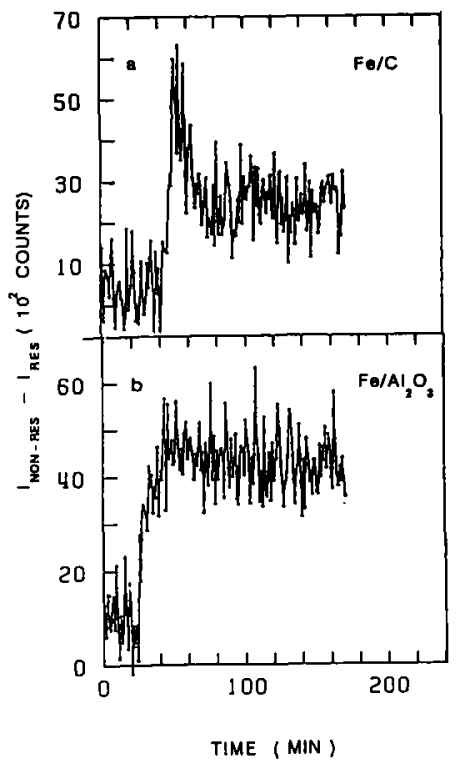

Fig. 2 Difference in $\gamma$-ray transmission between resonant and non-resonant energy as a function of time, while the catalyst is exposedto $\mathrm{H}_{2} \mathrm{~S} / \mathrm{H}_{2}$ gas mixture at room temperature. differs for the carbon and alumina-supported catalysts. For the $\mathrm{Fe} / \mathrm{Al}_{2} \mathrm{O}_{3}$ catalyst it is observed that the amount of the high-spin $\mathrm{Fe}^{2+}$ phase increases during the first 20 minutes and then stays constant in time. From Fig. 1 a it can be concluded that the formation of the the highspin $\mathrm{Fe}^{2+}$-phase is hardly followed by other reactions. So, the catalyst will consist of the original iron (III) oxide and a high-spin $\mathrm{Fe}^{2+}$ phase after the sulfidation treatment at room temperature. For the $\mathrm{Fe} / \mathrm{C}$ catalyst the increase in the amount of the high-spin $\mathrm{Fe}^{2+}$-phase is followed by a decrease and stabalizes at a certain level. As it turns out that after the high temperature sulfidation treatment the high-spin $\mathrm{Fe}^{2+}$-phase is completely transformed into other phases (see Fig. 1 a) it can be concluded that this transformation already partly occurs at room temperature.

During the sulfidation of the oxidic catalyst precursor, oxygen ions are replaced by sulfur ions. Due to the relatively high mass number of sulfur the $\gamma$-ray transmission of such a catalyst sample will substantially decrease upon such a replacement. During the sulfidation process both adsorption of $\mathrm{H}_{2} \mathrm{~S}$ on the catalyst particles and deposition of elemental sulfur will decrease the $\gamma$-ray transmission also. The $\gamma$-ray transmission at the non-resonant energy has been used to determine the amount of sulfur present in the catalyst. Calibration has been performed by measuring the $\gamma$-ray transmission of a fixed amount of the catalyst mixed together different amounts of elemental sulfur.

In order to determine the number of sulfur atoms per metal atom in the catalyst, the observed total amount of sulfur uptake in the sample has to be corrected for the adsorption of $\mathrm{H}_{2} \mathrm{~S}$ on the catalyst particles as well as on the support and the sulfur possibly deposited on the support. The gas adsorption takes place during cooling down the sample from the sulfidation temperature to room temperature and is determined from the decrease in $\gamma$-ray transmission during this process. By measuring the $\gamma$-ray transmission of the blank support during subsequent sulfidation treatments, it is found that only $\mathrm{H}_{2} \mathrm{~S}$ adsorption occurs on the carbon-support. In the case of the alumina-support it turns out that besides the $\mathrm{H}_{2} \mathrm{~S}$ adsorption, above $673 \mathrm{~K}$ also sulfur is deposited on or bound to the support material. However, the preliminary results for the alumina-supported catalysts are not accurate enough so far, so we will focus on the results for the carbon-supported Mo, Fe and FeMo catalysts which are given in Table 1.

For the Mo/C catalyst a ratio $\mathrm{S} / \mathrm{Mo}=1.5 \mathrm{at} / \mathrm{at}$ is observed after sulfidation of the sample in $\mathrm{H}_{2} \mathrm{~S} / \mathrm{H}_{2}$ gas at $373 \mathrm{~K}$. At increasing sulfidation temperatures the S/Mo ratio increases to 2.8 after sulfidation at $773 \mathrm{~K}$. Such a surprisingly high $S /$ Mo ratio is also found by Candia et al. $/ 6 /$ and Bouwens et al. /7/ for sulfided $\mathrm{Mo} / \mathrm{Al}_{2} \mathrm{O}_{3}$ and Mo/C catalysts from EXAFS results. For the $\mathrm{Fe} / \mathrm{C}$ catalyst the $\mathrm{S} / \mathrm{Fe}$ ratio decreases from 1.7 after sulfidation at $373 \mathrm{~K}$ to about 0.9 after sulfidation at $673 \mathrm{~K}$. This deduced behaviour of the $\mathrm{S} / \mathrm{Fe}$ ratio is in reasonable agreement with the one determined from the spectral composition of the catalyst after various sulfidation treatments /3/. For the FeMo/C catalyst it is found that the uptake of sulfur by the catalyst is decreasing with increasing sulfidation temperature. The S/Metal ratio decreases from 1.5 to 1.0 by increasing the 
Table 1

Sulfur contents and sulfur to metal ratios determined both from the sulfur content of the catalyst as well as from the composition of the Mbssbauer spectra for carbon-supported Mo, $\mathrm{Fe}$ and FeMo catalysts after successive sulfidation treatments. In each sulfidation treatment the temperature of the catalyst is increased in $1 \mathrm{~h}$ linearly to the indicated temperature and subsequently cooled to room temperature.

\begin{tabular}{|c|c|c|c|c|c|c|c|c|}
\hline \multirow[b]{2}{*}{$\begin{array}{l}\text { Sulfidation } \\
\text { temperature }\end{array}$} & \multicolumn{3}{|l|}{$\mathrm{Mo} / \mathrm{C}$} & \multicolumn{2}{|l|}{$\mathrm{Fe} / \mathrm{C}$} & \multicolumn{2}{|c|}{ FeMo/C } & \multirow[b]{2}{*}{$\frac{\mathrm{S}(2)}{\mathrm{Fe}+\mathrm{Mo}}$} \\
\hline & $\begin{array}{c}\mathrm{S} \\
(\mathrm{mg})\end{array}$ & $\frac{\mathrm{s}(1)}{\text { Mo }}$ & $\begin{array}{c}\mathrm{S} \\
(\mathrm{mg})\end{array}$ & $\frac{\mathrm{S}(1)}{\mathrm{Fe}}$ & $\frac{\mathrm{s}(2)}{\mathrm{Fe}}$ & $\begin{array}{c}\mathrm{S} \\
(\mathrm{mg})\end{array}$ & $\frac{\mathrm{S}(1)}{\mathrm{Fe}+\mathrm{Mo}_{\mathrm{O}}}$ & \\
\hline $\begin{array}{r}300-373 \mathrm{~K} \\
-473 \mathrm{~K} \\
-573 \mathrm{~K} \\
-673 \mathrm{~K} \\
-773 \mathrm{~K}\end{array}$ & $\begin{array}{l}11.2 \\
12.6 \\
15.3 \\
17.3 \\
21.3\end{array}$ & $\begin{array}{l}1.5 \\
1.7 \\
2.0 \\
2.3 \\
2.8\end{array}$ & $\begin{array}{l}5.3 \\
3.9 \\
2.4 \\
2.8 \\
4.2 \\
\end{array}$ & $\begin{array}{l}1.7 \\
1.3 \\
0.8 \\
0.9 \\
1.3\end{array}$ & $\begin{array}{c}1.6 \\
1.1-1.7 \\
1.0 \\
1.1\end{array}$ & $\begin{array}{l}14.0 \\
13.2 \\
9.0 \\
9.0\end{array}$ & $\begin{array}{l}1.5 \\
1.4 \\
1.0 \\
1.0\end{array}$ & $\begin{array}{l}1.7 \\
1.7 \\
1.8 \\
1.8\end{array}$ \\
\hline
\end{tabular}

$S$ : total amount of sulfur present in the catalyst after the indicated sulfidation treatment, corrected for the $\mathrm{H}_{2} \mathrm{~S}$ gas adsorbed by the support. Experimental uncertainty $1.5 \mathrm{mg}$.

$\mathrm{S}(1) /$ Metal : Sulfur to metal ratio in atoms per atom as determined from mg $S$. Experimental uncertainty $<0.5$ at/at.

$\mathrm{s}(2) /$ Metal : Sulfur to metal ratio in atoms per atom as determined from Mossbauer spectra.

N.B. For FeMo/C catalyst a Fe-Mo-S structure consisting of MoS 2 slabs is assumed. Experimental uncertainty 0.1 at/at.

sulfidation temperature from $373 \mathrm{~K}$ to $773 \mathrm{~K}$. As the Mo loading is 4 times higher than the Fe loading, it follows from the S/Metal ratio that the Mo-phase will not be completely sulfided as in the case of the Mo/C catalyst. From the Mossbauer spectra it follows that a Fe-Mo-S phase is formed. In analogy to Co-Mo$S$ the Fe-Mo-S structure is considered as Fe-atoms at edge-sites of MoS 2 slabs /1/. Therefore, a much higher S/Metal ratio is expected when the Mo should be completely sulfided to $\mathrm{MoS}_{2}$, as is observed by EXAFS for CoMo/C /7/. So, a discrepancy in understanding still exists for sulfided FeMo/C catalysts.

We conclude that by combining Mossbauer spectroscopy and ordinary $\gamma$-ray transmission, valuable additional information can be obtained for characterizing the catalysts. This study will be continued by a further evaluation of the method and a thorough comparison of the outcoming results with those obtaind by other techniques.

\section{REFERENCES}

/1/ H. Topsфe, B.S. Clausen and S. Mфrup, Hyp. Int. 27(1986) 231

/2/ H. Juntgen, Fuel 65(1986) 1436

/3/ W.L.T.M. Ramselaar, E. Gerkema, R.H. Hadders, V.H.J. de Beer and A.M. van der Kraan, to be publ.

/4/ W.L.T.M. Ramselaar, M.W.J. Craje, E. Gerkema, V.H.J. de Beer and A.M. van der Kraan, accepted for publ. in Bul1. Soc. Chim. Belg. (1987)

/5/ A.M. van der Kraan, and J.W. Niemantsverdriet, in Industrial Applications of the MOssbauer Effect, eds. G.J. Long and J.G. Stevens (Plenum Press, New-York, 1986) p. 609

/6/ R.Candia, B.S. Clausen, J. Bartoldy, N.-Y. Topsфe, B. Lengeler and H. Topsфe, Proc. 8 th Int. Congr. Catalysis, Barlin, 1984, (Verlag Chemie, 1984) p. 375

$17 /$ S.M.A.M. Bouwens, D.C. Koningsberger, V.H.J. de Beer and R. Prins, accepted for publ. in Bull. Soc. Chim. Belg. (1987) 